\title{
Transformation of Local Culinary through Gastronomy Tourism
}

Serkan POLAT (https://orcid.org/0000-0002-9128-7443), Department of Gastronomy and Culinary Arts, İstanbul Medeniyet University, Turkey; e-mail: spolatt@gmail.com

Semra AKTAŞ-POLAT (https://orcid.org/0000-0002-2324-2200), Department of Tourism Management, Istanbul Medeniyet University, Turkey; e-mail: saktaspolat@gmail.com

\section{Gastronomi Turizmi Aracılığıyla Yerel Mutfağın Dönüșümü}

\begin{abstract}
Gastronomy comes from the combination of food with art, pleasure, taste, and science. In addition to food itself, the experience of the culture that food belongs to also directs people to rural areas, regions, and countries that makes food an essential attraction for tourism. The purpose of this paper is to present the transformation process of local culinary through gastronomy tourism. The structuralism approach was employed and the culinary triangle interpreted by Lévi-Strauss in the dilemma of culture and nature was taken as an exemplary model to achieve the goal. The model was transformed into a new triangle named as the Culinary Triangle in Gastronomy Tourism and evaluated in the context of cultural and artistic transformation. This new triangle consists of local, hybrid, and ornamental culinary.

Keywords

: $\quad$ Local Culinary, Lévi-Strauss, Culinary Triangle, Gastronomy Tourism.

JEL Classification Codes : Z130, Z320.

\section{$\ddot{O} z$}

Gastronomi, yiyeceğin bilim, sanat, haz ve lezzetle birleşiminden doğmaktadır. Yiyeceğin yanı sıra yiyeceğin ait olduğu kültürün deneyimlenmesi de insanları kırsal alanlara, bölgelere ve ülkelere yöneltmekte ve mutfağ 1 turizm için önemli bir çekim unsuru haline getirmektedir. Bu makalenin amac1 gastronomi turizmi aracılığıyla yerel mutfağın dönüşüm sürecini göstermektir. Amaca ulaşmak için yapısalcılık yaklaşımından yararlanılarak Lévi-Strauss'un kültür ve doğa ikileminde yorumladığı mutfak üçgeni örnek model olarak alınmıştır. Lévi-Strauss, toplumun analizinde yiyecek ve pişirmeye özel bir önem vermiştir. Yiyeceğin üç hali olarak tanımladığı çiğ, pişmiş ve çürümüş hali üzerinden toplumsal yapıyı analiz etmiştir. Bu model, yerel, hibrit ve süs mutfağından oluşan ve Gastronomi Turizminde Mutfak Üçgeni olarak adlandırılan yeni bir üçgene dönüştürülerek kültürel ve sanatsal dönüşüm bağlamında değerlendirilmiştir.
\end{abstract}

Anahtar Sözcükler : Y Yerel Mutfak, Lévi-Strauss, Mutfak Üçgeni, Gastronomi Turizmi. 


\section{Introduction}

Although food is an expanding topic, it has remained as a limited area for a long time (Drouard, 2015). The interest of social scientists on the subject was minimal (Zelinsky, 1985). However, the subject of food has become a legitimate research area in the social sciences for some time (Gregory, 2015). Gastronomy treated as science by Brillat-Savarin (1854) is defined as a phenomenon that combines food with art (Velissariou \& Vasilaki, 2014; Scarpato, 2003a). Gastronomy examines the relationship between culture and food as well as artistic characteristics (Kivela \& Crotts, 2006). Moreover de La Reynière (1808: 19) stated that the number of gourmets increased rapidly, gastronomy science became fashionable, and it spread to kitchens, halls, libraries, and theaters. On the other hand, it can be expressed that this expansion is very late in tourism. For example, according to Long (2013), food issue has not been emphasized in the hospitality industry until the 1990s.

Tourism is a powerful field for theorization of taste and culture (Stringfellow \& MacLaren \& Maclean \& O'Gorman, 2013). Gastronomy is an important component of tourism (Defert, 1987; Hall \& Mitchell, 2005; Hall \& Sharples, 2003). Moreover, food improves the tourist experience (Henderson, 2009) by providing tourists with travel experiences to their own culinary systems (Cook \& Crang, 1996). Tourists experience new cultures and countries through gastronomy tourism (Mitchell \& Hall, 2003). At the same time, tourists relate to not only the region's cultural and historical heritage but also traditions and history (Corigliano, 2003). Furthermore, a link between local culture, nature, and food is provided through the experience of gastronomy (Hjalager \& Richards, 2003).

The point to be noted is the commodification of gastronomy related elements through gastronomy tourism. In other words, the gastronomic identity defined as indispensable for tourism destination by Fox (2007) is commodified and the cultural sustainability of the gastronomy system is harmed (Hjalager \& Richards, 2003). Therefore, it is inevitable to deal with culture to investigate gastronomy tourism (Boniface, 2016).

Moreover, with the increasing of interest in food in the social sciences, the interest in gastronomy tourism has also gained momentum in recent years. Some of the topics covered in gastronomy tourism are the development of gastronomy tourism (Boniface, 2016; Hall \& Mitchell, 2001; Hjalager, 2003; Long, 1998), the contribution of gastronomy tourism (Fox, 2007; Montanari \& Staniscia, 2009), the socio-psychological effects of gastronomy tourism (Fields, 2003), and the touristic experiences for gastronomy tourism (Cook \& Crang, 1996; Kivela \& Crotts, 2006). In the literature, it is seen that gastronomy tourism is mentioned in different ways. For example; culinary tourism (Long, 1998), gastronomic tourism (Fields, 2003; Scarpato, 2003b; Zelinsky, 1985), tasting tourism (Boniface, 2016) or food tourism (Hall \& Mitchell, 2001).

In this article, the term of gastronomy tourism including all kind of travels for food and beverages (e.g. wine tourism, food tourism) is used in order to ensure the unity of meaning. Furthermore, gastronomy tourism acts as a bridge between past and future by protecting the living culinary culture and transporting it to the future generations. Without 
considering the social mechanisms behind the combination of food with art and the culture it belongs to it will have no other meaning than to fulfill the physical requirements. Therefore, an in-depth analysis of gastronomy tourism is important. This seems to be possible with structuralism based on the analogy (Beardsworth \& Keil, 2002) that focuses on the deep structures supporting them from the superficial connections.

In order to explain the invisible structure of gastronomy tourism with concrete elements, this article focuses on interpreting gastronomy tourism from a different framework based on the culinary triangle described by Claude Lévi-Strauss, who uses food and cooking as a language in understanding society. In order to reach the goal, the culinary triangle was explained by Lévi-Strauss's thoughts about cooking. Afterwards, the culinary triangle was interpreted within the framework of gastronomy tourism through analogy.

\section{Terminology and Theoretical Framework}

In general, the structuralists consider food as a language (Symons, 1994). LéviStrauss observed that there is no society that lacks any language, and there is no society that does not cook some of food sources (Leach, 1989). He also made a symbolic interpretation of the transition from nature to culture by emphasizing the temporary nature of similarity between language and society (Glucksmann, 2015). Therefore, the preservation and reconstruction of the culinary meaning is important because food reveals our essence according to Fine (1996).

Strauss interpreted cooking as a determinant feature of humanity (Wrangham, 2010) and the use of fire as a universal aspect of human behavior (Tremlett, 2014). According to Lévi-Strauss, the need for food causes paradox and cooking is one of the means of coping with this paradox (Murcott, 1988). Cooking plays the role of mediator between meat and fire (Lévi-Strauss, 1966). Thus, cooking indicates the transition between nature and culture (Brownlie \& Hewer \& Horne, 2005). According to this thought, meat reflects nature and natural, and fire reflects culture. Cooking is considered as a means of cultural transformation of the natural. Lévi-Strauss has explained this transformation via the culinary triangle model.

The culinary triangle is a summary cooking model (Lehrer, 1972). The culinary triangle, which is a basic set of contrasts in the types of cooking, indicates that contrasts are made in the social sphere (Shankman, 1969). In the culinary triangle, Lévi-Strauss interpreted different cooking processes and types on two axes (nature versus culture and normal versus transformed) that intersect (Glucksmann, 2015). The triangle describes the semantic area corresponding to the categories of raw-cooked-rotten (Lévi-Strauss, 1966). According to the triangle, a food can be raw, cooked or rotten. The cultural transformation of raw reflects the cooked and its natural transformation reflects the rotten (Lévi-Strauss, 1983).

By taking the analysis of Lévi-Strauss one step further, he added a second triangle consisting of a triangle of roasted, smoked, and boiled trimmings into the culinary triangle. The culinary triangle with this new structure is given in Figure 1. 


\section{Figure: 1 \\ Culinary Triangle}

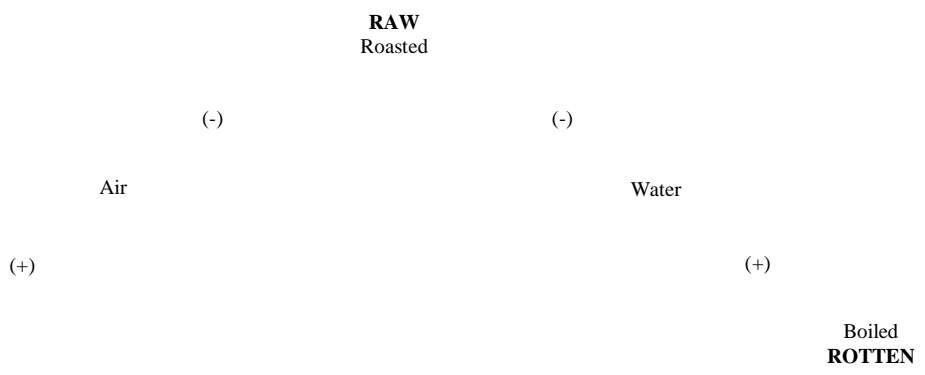

Source: Lévi-Strauss, 1966: 594.

Lévi-Strauss also commented on the meaning of the triangle for social analysis. According to Figure 1 (Lévi-Strauss, 1966, 1977, 2008);

- Roasted is close to the raw category because the inside and outside of food is not cooked evenly. Boiled is close to the rotten category because the lots of meat varieties are cooked together with vegetables (casserole) and the meat is crushed and overcooked. Smoked is close to the cooked category because it describes a slow and deep cooking.

- Roasting requires direct exposure to fire, boiling a cultural object (which holds both water and food).

- Boiling is interpreted as domestic kitchen referring to domestic use, and roasting is interpreted as an external kitchen used for guests.

- Boiling refers to the tightening of family and social ties, roasting refers to the loosening of family and social ties.

- Boiled symbolizes saving because it preserves meat and water on the other hand, roasted symbolizes extravagance because it is accompanied by destruction and devastation.

- Boiled represents the plebian, roasted represents the aristocrats.

- Smoked doesn't need to air and water, but it is cooked slowly and deeply as it is boiled.

- During smoking, there is nothing more than air between fire and meat as in roasting. The technical difference between the two is that air is reduced to a minimum in roasted while it is maximized in smoked.

Lévi-Strauss's approach has opened up new horizons for understanding cultural facts (Hammel, 1967). Mäkelä and Arppe (2005) stated that the movement from nature to culture expresses a progress and a reverse movement expresses a decline. Brzostek (2017) reached the sonaristic triangle of acoustics, electro acoustics, and electronics by placing the modern and postmodern instead of nature and culture at both ends of the triangle. 
Hage (1979) interpreted the culinary triangle with the transformation of persons through rituals and stated that humans could be symbolically transformed by cooking. Hage (1979) also stated that a person can be transformed into raw by extreme melioration, and a structure that has lost its social degeneration or purity can be associated with rotten. The basic culinary triangle composed of raw-cooked-rotten defines the three-pole gastronomy system as described by Clark (2004).

\section{Methodology}

This study focuses on the relationship between gastronomy and tourism by constructing an analogy with the culinary triangle through structuralism approach. LéviStrauss, the pioneer of structural anthropology, developed structuralism for the analysis of societies that lived in pre-literate periods (Bocock, 2009).

According to Eagleton (2008: 87) “The word 'structuralism' itself indicates a method inquiry, which can be applied to a whole range of objects from football matches to economic modes of production...." Similarly, Piaget (2015) states that structuralism is not a teaching but a method. Structuralism based on analogy focuses on deep structures supported by the surface connections (Beardsworth \& Keil, 2002).

In order to achieve the goal, the structuralism approach was employed, and the culinary triangle interpreted by Lévi-Strauss in the dilemma of culture and nature was taken as an exemplary model. The model transformed into a new triangle named as the Culinary Triangle in Gastronomy Tourism was evaluated in the context of cultural and artistic transformation.

\section{The Culinary Triangle in Gastronomy Tourism}

The name of the basic culinary triangle has been transformed into the Culinary Triangle in Gastronomy Tourism by interpreting culture and art dilemma in the context of gastronomy tourism. In this new triangle shown in Figure 2, the raw, cooked, and rotten areas of the basic culinary triangle were replaced by local, hybrid, and ornamental. In this triangle, the cultural transformation of the local culinary shows the hybrid culinary and the artistic transformation shows the ornamental culinary. Local culinary can be combined with tastes from different cultures to become a hybrid culinary. Nevertheless, the local culinary can lose its essence and become artificial through exaggerated touches that result in losing its originality and turning to ornamental culinary. 


\section{Figure: 2 \\ The Culinary Triangle in Gastronomy Tourism}

LOCAL

$(-)$

New Culture
$(-)$

Science \& Art
$(+)$

HYBRID
$(+)$

ORNAMENTAL

Source: Prepared by the authors.

\section{Local culinary}

The local culinary consists of food and beverages specific to a particular area, region or country. For example, pizza, pasta, mozzarella, parmesan, and Toscana wines symbolize Italy in the whole world while yogurt, Turkish kebabs, Turkish delight, and Turkish coffee brings to mind Turkey. Moreover, the local culinary symbolizes the socio-cultural values related to food and beverages such as eating habits and table manners. On the other hand, the local culinary points to those people looking for their own roots and essence or those looking for local flavors. The local culinary also refers to a structure where the socio-cultural effects of tourism are not reflected in the daily life of destination that result in preserving the originality of the destination.

Demand for rural and natural products has increased in the kitchen due to the side effects of industrial production (Bessière, 1998). The local culinary culture specific to a destination attracts tourists. For the tourist, the experience of local culinary has become a tool for the elimination of the longing for the cultural elements in daily life. According to a study conducted by the National Restaurant Association of America (2018), it is revealed that the guests want to see their return to the locality of their lifestyles in restaurants. Food is one of the last authentic areas tourists can buy (Reynolds, 1993). Furthermore, tourism plays a balancing role for those seeking authenticity (Aktaş-Polat \& Polat, 2016). Tourists are looking for the originality that they cannot find in the areas where they live in.

Local culinary can be used as an element of attraction for people looking for authentic, different, new, and original tastes. The effective use of this attraction will contribute positively to rural and regional development. On the other hand, it is of great importance to act planned to make this development sustainable. In the name of economic growth, the inclusion of local culinary in unplanned tourism mobility may cause some negative consequences in the medium and long terms. For example, changes in the ingredients of local dishes, preparation process, cooking technique, and presentation style can be made for more economic gain. This change will eventually lead to the loss of the originality of local tastes over time. Therefore, tourists visiting the region for their original 
tastes will start to look for different flavors instead of these delicacies lost their originality and will turn to alternative regions. Moreover, another negative result of unplanned action is the change or deterioration of the social, economic, environmental, and cultural environment of the local area due to tourism. For this reason, it is very important for local culinary and the region to benefit from the local culinary in accordance with the principles of sustainable development in tourism.

\section{Hybrid culinary}

The hybrid culinary consists of a combination of different local cuisines. Different local cuisines can come together in two ways. First, it can be realized through the movements of people living in different regions or countries due to reasons such as work, education, foreign marriages, secondary housing, war, economic crisis, political crisis, and natural disaster. The other way can be realized through tourism. A tourism destination is the blending point of different cultures. The interaction of local people with tourists from different cultures will cause some changes on the local community and tourists. The local cuisine is one of these changes occurred in local areas. The hybrid culinary refers to a structure where tourism changes the daily life of destinations.

Tourists are also exploring the cuisine of the region in the evaluation stage of alternative destinations they will go on holiday. In other words, some of these tourists are looking for their own cuisine and delicacies in the cuisine of their holiday destination. On the other hand, some of these tourists demand different and new cuisines and delicacies in their holiday destination. The hybrid culinary offers opportunities to satisfy the needs, expectations, and desires of these two types of tourists. Food and drinks that tourists bring along with them can cause changes in the local culinary. Moreover, local people and businesses can also make some changes on the local dishes to meet the expectations and demands of tourists. This change does not mean the complete disappearance of local tastes as a radical transformation. However, the failure to control this change may lead to the disappearance of the local cuisine.

In the culinary triangle the cooked has been replaced by hybrid culinary. The hybrid culinary referring to alienating to the local was placed in the cooked area. A tourism destination that opens its doors to tourists changes through the socio-cultural effects of tourism.

Appadurai (2000) defined tourists as people who mediated the change of the world in which we live, such as immigrants, refugees, exiles, expats, and other moving groups. In addition to the tourist flows, the dishes of the local culinary are moved to a different culture and gained a new identity, while the culture of tourists influences the local culture and causes the culture to change over time. Thus, cultural interaction allows meeting hybrid tastes.

On the one hand, globalization and media presentations (Beaugé, 2012), on the other hand, the copying of food is in question due to the fact that food is quickly spoiled and 
cannot be moved (Reynolds, 1993). According to Beauge (2012), this situation causes the loss of history and symbolic structures.

The elements that attract the interest of tourists are copied and the features that make a tourism destination unique are blurred. As a result of touristic mobility, food and food preparation methods are also flowing. Moreover, with this flow, the tastes specific to the local cuisine are copied and transferred to other cultures and blended with the new culture and transformed into a new taste. The local culinary combined with tastes from different cultures can take the form of a hybrid culinary.

In summary, it is possible to see two conclusions of tourist mobility here. The former is that tourist activities cause the emergence of hybrid culinary, and the latter is that tourists try to satisfy the longing for the new one by visiting the hybrid culinary. Fusion cuisine can be given as an example described by concepts such as multiculturalism and interculturalism (Scarpato \& Daniele, 2003). Fusion cuisine provides both mental and visual satisfaction with a hybrid presentation by dissolving different cultures in a pot.

\section{Ornamental culinary}

In the culinary triangle the rotten has been replaced by the ornamental culinary. The ornamental culinary is an artificial state with exaggerated touches on the local culinary and defines the loss of authenticity of the local culinary. Therefore, it is placed in the rotten area of the model. The artistic practices applied in the culinary prevented the taste of food and it can be said that the local culinary has lost its originality and turned into ornamental culinary.

Barthes (1961) has made the definition of the ornamental culinary. Barthes (1961) used the concept of ornamental based on the fancy food photographs he saw in a magazine while he was investigating the topic of semiotics.

Unlike the local culinary, the ornamental culinary also symbolizes the changing and transforming of tourism destination. At the same time, the ornamental culinary points to tourists who are away from the pursuit of originality and focuses on flashing. The factors such as prestige and snobism (Naramski \& Herman \& Szromek, 2014), which are among the motivating factors in tourist consumption, cause tourists to focus on vanity and appearance rather than content. In other words, we can think of ornamental culinary as a means of conspicuous consumption described by Veblen (1918) to show others its richness and to increase social dignity (O’Cass \& McEven, 2004).

Nouvelle cuisine, haute cuisine, molecular gastronomy, and Note by Note ( $\mathrm{NbN})$ cuisine are examples of the ornamental culinary. Nouvelle cuisine is based on innovation and experience (Gillespie, 1994). Its real purpose is mental satisfaction (Berghous, 2001). Furthermore, nouvelle cuisine is expensive by nature (Mennell, 1985). It describes quality and expensive in addition to surprising, exciting, and unorthodox (Cracknell \& Nobis, 1989). On the other hand, haute cuisine, which can be considered as an artistic indicator (Svejenova 
\& Mazza \& Planellas, 2007), is interpreted as a glorious, archaic (Gault, 1996), served in ornamented places and aristocrats' culinary (Trubek, 2000).

Molecular gastronomy, which fills the gap between art, craft, and science (van der Linden \& McClements \& Ubbink, 2008), is defined as the science of food and entertainment (Kurti \& This-Benckhard, 1994). NbN cuisine applications which mean cooking with pure compounds with molecular gastronomy (This, 2013a) are applications that bring gastronomy to science and offer more freedom and options to consumers (This, 2013b).

These culinary practices offer diversity for both daily and tourist consumption as an alternative to the local culinary with food and menus produced by different means and methods. Tourists will be different from others with the special knowledge and skills that they acquired through travel (Riley, 1995). Moreover, they will realize their hedonic aims in fine dining restaurants (Hwang \& Ok, 2013; Ryu \& Han, 2011) and gain respect and prestige (Henderson, 2004; Warde, 1997). Thus, tourists will meet the need for self-esteem that Maslow mentioned in the hierarchy of needs (Tikkanen, 2007).

In tourism mobility, it can be said that food, tourists eat in tourism destinations where they travel, is the status tool and the ornamental culinary fills the status gap that tourists feel in their daily lives. The most important elements of ornamental culinary are the presentation and service style of food, the identity of the chef who prepares food, the identity of the place where food is eaten, the identity of consumers in the place and the price paid for food.

\section{Conclusion}

Lévi-Strauss (1966) interpreted cooking as a language based on raw, cooked, and rotten in the basic culinary triangle. By focusing on the phenomenon of cooking, he interprets the transition between nature and culture, and enlightens the analysis of social structure.

In this study, the culinary triangle is examined in the context of gastronomy tourism. Gastronomy tourism is defined as an agent of cultural and artistic transformation through local, hybrid, and ornamental culinary. However, gastronomy tourism has been discussed in the context of tourist motivation and socio-cultural effects of tourism in tourism destinations. In gastronomy tourism, the corners of the culinary triangle are named as local, hybrid and ornamental culinary.

Firstly, the local culinary is similar to the raw one because it describes the original and unique food of the society. With this feature, it is the culinary demanded by those tourists alienated from their culture and they are looking for traditional, authentic, and creative experiences. Therefore, the local culinary has taken on the meaning of the raw in the culinary triangle. While the raw reflects what is not transformed in natural or cultural, the local culinary reflects what is not transformed in cultural or artistic. 
Secondly, the hybrid culinary is similar to the cooked because of the fact that it defines unfamiliarity to the local culinary. The cooked reflects the cultural transformation of the raw in the culinary triangle. In gastronomy tourism, the hybrid culinary reflects the cultural transformation of the local culinary as a result of intercultural mobility. Hybrid culinary attracts those tourists who want to get away from the traditional and want to taste hybrid tastes.

Finally, the ornamental culinary is similar to the rotten because it defines the loss of authenticity of the local culinary. While the culinary triangle reflects the natural transformation of the raw, the ornamental culinary in gastronomy tourism reflects the artistic transformation of the local culinary. The ornamental culinary describes the culinary demanded by the tourists who want to feel special in addition to social status and vanity. Although all luxury restaurants are not included, some fine dining restaurants serving the products of the nouvelle cuisine and haute cuisine, which transform food into a different taste through science and art, offer fancy alternatives for tourists who see vacation even food they consume during their vacations as a social status tool.

With the culinary triangle model in gastronomy tourism, an important step has been taken in the interpretation of gastronomy tourism from a structuralist perspective. The structural analysis of gastronomic tourism can be enriched by including other stakeholders of tourism (e.g. public authorities, local people, private sector) to the model in order to be able to explain all aspects of this structural relationship in the future researches. Nevertheless, it is thought that this study presents a general framework for the structural analysis of gastronomy tourism. Moreover, the fact that gastronomy tourism is maintained on the ground of artistic and cultural transformation makes this work important. It emphasizes the importance of preserving and sustaining local cuisine and transferring it to the future generations. It is emphasized that national and local foods and beverages may lose their authenticity due to economic interest. Both national and local policy makers and decision makers should be reminded of the negative effects of tourism and should be more careful in the policy making process. The private sector, especially the enterprises operated by the local people, should show the necessary sensitivity to protect the cuisine of the region and country in which they operate.

\section{References}

Aktaş-Polat, S. \& S. Polat (2016), "Turizm Perspektifinden Yabancılaşmanın Sosyo-Psikolojik Analizi: Günlük Yaşamdan Turistik Yaşama Yabanc1laşma Döngüsü”, Sosyoekonomi, 24(28), 235-253.

Appadurai, A. (2000), "Grassroots Globalization and the Research Imagination”, Public Culture, 12(1), 1-19.

Barthes, R. (1961), "Pour une Psycho-Sociologie de L'alimentation Contemporaine", Annales. Économies, Sociétés, Civilisations, 16(5), 977-986.

Beardsworth, A. \& T. Keil (2002), Sociology on the Menu: An Invitation to the Study of Food and Society, London: Routledge. 
Beaugé, B. (2012), “On the Idea of Novelty in Cuisine: A Brief Historical Insight”, International Journal of Gastronomy and Food Science, 1(1), 5-14.

Berghous, G. (2001), “The Futurist Banquet: Nouvelle Cuisine or Performance Art?”, New Theatre Quarterly, 17(1), 3-17.

Bessière, J. (1998), "Local Development and Heritage: Traditional Food and Cuisine as Tourist Attractions in Rural Areas", Sociologia Ruralis, 38(1), 21-34.

Bocock, R. (2009), Consumption, London and New York: Routledge.

Boniface, P. (2016), Tasting Tourism: Travelling for Food and Drink, Routledge.

Brillat-Savarin, J.A. (1854), The Physiology of Taste: or, Transcendental Gastronomy, (F. Robinson, trans.), Philadelphia: Lindsay \& Blakiston.

Brownlie, D. \& P. Hewer \& S. Horne (2005), "Culinary Tourism: An Exploratory Reading of Contemporary Representations of Cooking”, Consumption, Markets and Culture, 8(1), 726.

Brzostek, D. (2017), “The Sonoristic Triangle, or, what Claude LéviStrauss would have Said about Sound Culture if He had not Talked about Cooking Instead", AVANT, VIII(1), 93-100.

Clark, D. (2004), “The Raw and the Rotten: Punk Cuisine”, Ethnology, 43(1), 19-31.

Cook, I. \& P. Crang (1996), "The World on a Plate Culinary Culture, Displacement and Geographical Knowledges", Journal of Material Culture, 1(2), 131-153.

Corigliano, M.A. (2003), “The Route to Quality: Italian Gastronomy Networks in Operation”, in: A. Hjalager \& G. Richards (eds.), Tourism and Gastronomy, London and New York: Taylor \& Francis Group, 166-185.

Cracknell, H.L. \& G. Nobis (1989), "Principles of Nouvelle Cuisine", in: The New Catering Repertoire: Volume I Aide-Mémoire du chef, Van Nostrand Reinhold, 738-744.

de La Reynière, G. (1808), Manuel des Amphitryons, Paris: Capelle et Renand.

Defert, P. (1987), “Tourisme et Gastronomie", The Tourist Review, 42(3), 7-8.

Drouard, A. (2015), "Food, Sociology of”, International Encyclopedia of the Social \& Behavioral Sciences, $2^{\text {nd }}$ Edition, 9, 311-315.

Eagleton, T. (2008), Literary Theory an Introduction, Minneapolis: Anniversary Edition, University of Minnesota Press.

Fields, K. (2003), "Demand for the Gastronomy Tourism Product: Motivational Factors", in: A-M. Hjalager \& G. Richards (eds.), Tourism and Gastronomy, London and New York: Taylor \& Francis Group, 36-50.

Fine, G.A. (1996), Kitchens: The culture of Restaurant Work, Berkeley: University of California Press.

Fox, R. (2007), "Reinventing the gastronomic Identity of Croation Tourist Destinations", Hospitality Management, 26, 546-559.

Gault, H. (1996), "Nouvelle Cuisine", in: H. Walker (ed.), Cooks and Other People: Proceedings of the Oxford Symposium on Food and Cookery 1995, (H. Walker, trans.). England: Prospect Books, 123-127.

Gillespie, C.H. (1994), “Gastrosophy and Nouvelle Cuisine: Entrepreneurial Fashion and Fiction”, British Food Journal, 96(10), 19-23. 
Glucksmann, M. (2015), Structuralist Analysis in Contemporary Social Thought, a Comparison of the Theories of Claude Lévi-Strauss and Louis Althusser, Routledge Library Editions: Social Theory.

Gregory, S. (1995), "Using Qualitative Research for the Sociology of Food”, British Food Journal, 97(7), 32-35.

Hage, P. (1979), “Symbolic Culinary Mediation: A Group Model”, Man, New Series, 14(1), 81-92.

Hall, C.M. \& R.D. Mitchell (2001), "Wine and Food Tourism”, in: N. Douglas \& N. Douglas \& R. Derrett (eds.), Special Interest Tourism: Context and Cases, Australia: John Wiley \& Sons, 307-329.

Hall, C.M. \& R.D. Mitchell (2005), "Gastronomic Tourism-Comparing Food and Wine Tourism Experiences”, in: M. Novelli (ed.), Niche Tourism Contemporary Issues, Trends and Cases, Butterworth-Heineman: Elsevier, 73-88.

Hall, C.M. \& L. Sharples (2003), "The Consumption of Experiences or the Experience of Consumption? An Introduction to Tourism of Taste", in: C.M. Hall \& L. Sharples \& R. Mitchell \& N. Macinos \& B. Cambourne (eds.), Food Tourism Around the World, Development, Management and Markets, Butterworth-Heineman: Elsevier, 1-24.

Hammel, E.A. (1967), "Sexual Symbolism in Flatware”, Kroeber Anthropological Society Papers, 37, 23-30.

Henderson, J.C. (2004), "Food as a Tourism Resource: A View from Singapore”, Tourism Recreation Research, 29(3), 69-74.

Henderson, J.C. (2009), “Food Tourism Reviewed”, British Food Journal, 111(4), 317-326.

Hjalager, A-M. (2003), “A Typology of Gastronomy Tourism”, in: A-M. Hjlager \& G. Richards (eds.), Tourism and Gastronomy, London and New York: Taylor \& Francis Group, 2135.

Hjalager, A-M. \& G. Richards (2003), “Still Undigested: Reserach Issues”, in: A-M. Hjlager \& G. Richards (eds.), Tourism and Gastronomy, London and New York: Taylor \& Francis Group, 224-234.

Hwang, J. \& C. Ok (2013), "The Antecedents and Consequence of Consumer attitudes Toward Restaurant Brands: A Comparative Study Between Casual and Fine Dining Restaurants", International Journal of Hospitality Management, 32, 121-131.

Kivela, J. \& J.C. Crotts (2006), “Tourism and Gastronomy: Gastronomy's Influence on How Tourists Experience a Destination”, Journal of Hospitality and Tourism Research, 30(3), 354-377.

Kurti, N. \& H. This-Benckhard (1994), "Chemistry and Physics in the Kitchen”, Scientific American, 270(4), 66-71.

Leach, E. (1989), Claude Lévi-Strauss, Chicago: University of Chicago Press.

Lehrer, A. (1972), "Cooking Vocabularies and the Culinary Triangle of Levi-Strauss”, Anthropological Linguistics, 155-171.

Lévi-Strauss, C. (1966), “The Culinary Triangle”, Partisan Review, 33(4), 586-595.

Lévi-Strauss, C. (1977), “The Roast and the Boiled”, in: J. Kuper (ed.), The Anthropologists' Cookbook, Universe Books, 221-230.

Lévi-Strauss, C. (1983), Mythologiques the Raw and the Cooked (Volume One), Chicago: University of Chicago Press. 
Lévi-Strauss, C. (2008), “The Culinary Triangle”, in: C. Counihan \& P. van Esterik (eds.), Food and Culture a Reader, ( $3^{\text {rd }}$ Ed.), New York and London: Routledge, Taylor \& Francis Group, 40-47.

Long, L. (2013), “Culinary Tourism”, in: P.B. Thompson \& D.M. Kaplan (eds.), Encyclopedia of Food and Agricultural Ethics, Netherlands: Springer, 452-458.

Long, L.M. (1998), "Culinary Tourism: A Folkloristic Perspective on Eating and Otherness", Southern Folklore; Lexington, Ky. 55(3), 181-204.

Mäkelä, J. \& T. Arppe (2005), “Lévi-Strauss Culinary Triangle and the Living Foods Diet”, The 7th Conference of European Sociological Association. Rethinking, Inequalities, Torun, 9-12 September 2005.

Mennell, S. (1985), All Manners of Food: Eating and Taste in England and France from the Middle Ages to the Present, B. Blackwell.

Mitchell, R. \& C. Hall (2003), "Consuming Tourists: Food Tourism Consumer Behavior”, in: C.M. Hall et al., (eds.), Food Tourism around the World, Development, Management and Markets, Butterworth-Heineman: Elsevier, 60-80.

Montanari, A. \& B. Staniscia (2009), "Culinary Tourism as a Tool for Regional Re-Equilibrium”, European Planning Studies, 17(10), 1463-1483.

Murcott, A. (1988), "Sociological and Social Anthropological Approaches to Food and Eating", World Review Nutrition and Dietetics, 55, 1-40 (Basel Kargel).

Naramski, M. \& K. Herman \& A.R. Szromek (2014), "Instrumenty Promocji Produktu Turystycznego i ich Rola w Promowaniu Aktywności Turystycznej”, Rozprawy Naukowe Akademii Wychowania Fizycznego we Wrocławiu, 45, 119-129.

National Restaurant Association (2018), What's hot culinary forecast, <https://www.restaurant.org/News-Research/Research/What-s-Hot>, 23.01.2019.

O’Cass, A. \& H. McEven (2004), "Exploring Consumer Status and Conspicuous Consumption”, Journal of Consumer Behavior, 4(1), 25-39.

Piaget, J. (2015), Structuralism, (C. Maschler, trans. and ed.), Psychology Press.

Reynolds, P.C. (1993), "Food and Tourism: Towards an Understanding of Sustainable Culture", Journal of Sustainable Tourism, 1(1), 48-54.

Riley, R.W. (1995), "Prestige-Worthy Tourism Behavior”, Annals of Tourism Research, 22(3), 630649.

Ryu, K. \& H. Han (2011), "New or Repeat Customers: How does Physical Environment Influence Their Restaurant Experience?", International Journal of Hospitality Management, 30(3), 599-611.

Scarpato, R. (2003a), "Gastronomy as a Tourist Product: The Perspective of Gastronomy Studies", in: A-M. Hjalager \& G. Richards (eds.), Tourism and Gastronomy, London and New York: Taylor \& Francis Group, 51-70.

Scarpato, R. (2003b), "Sustainable Gastronomy as a Tourist Product”, in: A-M. Hjalager \& G. Richards (eds.), Tourism and Gastronomy, London and New York: Taylor \& Francis Group, 132-152.

Scarpato, R. \& R. Daniele (2003), "New Global Cuisine: Tourism, Authenticity and Sense of Place in Postmodern Gastronomy", in: C.M. Hall et al., (eds.), Food Tourism Around the World, Development, Management and Markets, Butterworth-Heinemann: Elsevier, 296313. 
Shankman, P. (1969), “Le roti et le Bouilli: Lévi-Strauss' Theory of Cannibalism”, American Anthopologist, 71(1), 54-69.

Stringfellow, L. \& A. MacLaren \& M. Maclean \& K. O’Gorman (2013), “Conceptualizing Taste: Food, Culture and Celebrities", Tourism Management, 37, 77-85.

Svejenova, S. \& C. Mazza \& M. Planellas (2007), "Cooking up Change in Haute Cuisine: Ferran Adrià as an Institutional Entrepreneur”, Journal of Organizational Behavior, 28(5), 539561.

Symons, M. (1994), “Simmel’s Gastronomic Sociology: An Overlooked Essay”, Food and Foodways: Explorations in the History and Culture of Human Nourishment, 5(4), 333351.

This, H. (2013a), "Celebrate Chemistry. Recent Results of Molecular Gastronomy”, European Review, 21(2), 158-174.

This, H. (2013b), "Molecular Gastronomy is a Scientific Discipline, and Note by Note Cuisine is the Next Culinary Trend", Flavour, 2(1), 1-8.

Tikkanen, I. (2007), "Maslow's Hierarchy and Food Tourism in Finland: Five Cases", British Food Journal, 109(9), 721-734.

Tremlett, P-F. (2014), Lévi-Strauss on Religion: The Structuring Mind, New York, USA: Routledge.

Trubek, A.B. (2000), Haute Cuisine: How the French Invented the Culinary Profession, Philadelphia: University of Pennsylvania Press.

van der Linden, E. \& D.J. McClements \& J. Ubbink (2008), "Molecular Gastronomy: A Food Fad or an Interface for Science-Based Cooking?", Food Biophysics, 3, 246-254.

Veblen, T. (1918), The Theory of the Leisure Class. An Economic Study of Institutions, New York: B.W. Huebsch.

Velissariou, E. \& E. Vasilaki (2014), "Local Gastronomy and Tourist Behavior: Research on Domestic Tourism in Greece", Journal of Tourism Research, 9, 120-143.

Warde, A. (1997), Consumption, Food and Taste, London: Sage Publications.

Wrangham, R. (2010), Catching Fire: How Cooking Made Us Human, Great Britain: Profile Books.

Zelinsky, W. (1985), “The Roving Palate: North America's Ethnic Restaurant Cuisines”, Geoforum, 16(1), 51-72. 